\title{
Heat-flow and subsurface temperature history at the site of Saraya (eastern Senegal)
}

\author{
F. Lucazeau ${ }^{1}$ and F. Rolandone ${ }^{2}$ \\ ${ }^{1}$ Dynamique des Fluides Géologiques, Institut de Physique du Globe de Paris/Sorbonne Paris Cité, UMR CNRS 7154, \\ 1 rue Jussieu, 75238, Paris cedex 05, France \\ ${ }_{2}^{2}$ STeP, Université Pierre et Marie Curie, 4 place Jussieu, 75252, Paris cedex 05, France
}

Correspondence to: F. Lucazeau (lucazeau@ipgp.fr)

Received: 2 May 2012 - Published in Solid Earth Discuss.: 4 June 2012

Revised: 12 July 2012 - Accepted: 17 July 2012 - Published: 20 August 2012

\begin{abstract}
New temperature measurements from eight boreholes in the West African Craton (WAC) reveal superficial perturbations down to $100 \mathrm{~m}$ below the alteration zone. These perturbations are both related to a recent increase in the surface air temperature (SAT) and to the site effects caused by fluid circulations and/or the lower conduction in the alterites. The ground surface temperature (GST), inverted from the boreholes temperatures, increased slowly in the past $\left(\sim 0.4^{\circ} \mathrm{C}\right.$ from 1700 to 1940$)$ and then, more importantly, in recent years $\left(\sim 1.5^{\circ} \mathrm{C}\right.$ from 1940 to 2010$)$. This recent trend is consistent with the increase of the SAT recorded at two nearby meteorological stations (Tambacounda and Kedougou), and more generally in the Sahel with a coeval rainfall decrease. Site effects are superimposed to the climatic effect and interpreted by advective (circulation of fluids) or conductive (lower conductivity of laterite and of highporosity sand) perturbations. We used a 1-D finite differences thermal model and a Monte-Carlo procedure to find the best estimates of these site perturbations: all the eight borehole temperature logs can be interpreted with the same basal heatflow and the same surface temperature history, but with some realistic changes of thermal conductivity and/or fluid velocity. The GST trend observed in Senegal can be confirmed by two previous borehole measurements made in 1983 in other locations of West Africa, the first one in an arid zone of northern Mali and the second one in a sub-humid zone in southern Mali. Finally, the background heat-flow is low $\left(31 \pm 2 \mathrm{~mW} \mathrm{~m}^{-2}\right)$, which makes this part of the WAC more similar with the observations in the southern part $(33 \pm 8$ $\mathrm{mW} \mathrm{m}{ }^{-2}$ ) rather than with those in the northern part and in the Pan-African domains where the surface heat-flow is 15$20 \mathrm{~mW} \mathrm{~m}^{-2}$ higher.
\end{abstract}

\section{Introduction}

Surface heat-flow provides a direct information on the thermal structure of the lithosphere. On the continents, the cratons have been stable for more than $1000 \mathrm{Myr}$ and their temperature distribution is near the conductive equilibrium (Jaupart and Mareschal, 2007), with the notable exception of the near surface perturbed by the past climatic fluctuations and/or the meteoric fluids circulations. Heat-flow is usually obtained at the Earth's surface as the product of the temperature gradient measured at thermal equilibrium in shallow boreholes (typically 100 to $1000 \mathrm{~m}$ ) by the thermal conductivity measured in the laboratory, preferentially on cores from these boreholes. Therefore, where the thermal gradient is recorded, it is also where the equilibrium is most likely perturbed and it is, therefore, essential to understand where and how it is actually perturbed. On the other hand, the perturbations in boreholes related to the climatic fluctuations provide further information on the traditional proxies used to reconstruct the past surface temperature history (Huang et al., 2000), especially on the low-frequency variations (Moberg et al., 2005). The significance of the temperature reconstructions based on borehole measurements relies, therefore, on the assumption that no other perturbation exists, but mostly the suspect data are selected arbitrarily.

Heat-flow measurements are not well distributed at the Earth's surface and there still exists undocumented areas in Africa or South America. These areas also lack for longterm air temperature records and climatic proxies and, therefore, new borehole measurements can provide essential information for the climatic evolution of equatorial and tropical areas. Here, we present eight new measurements from 

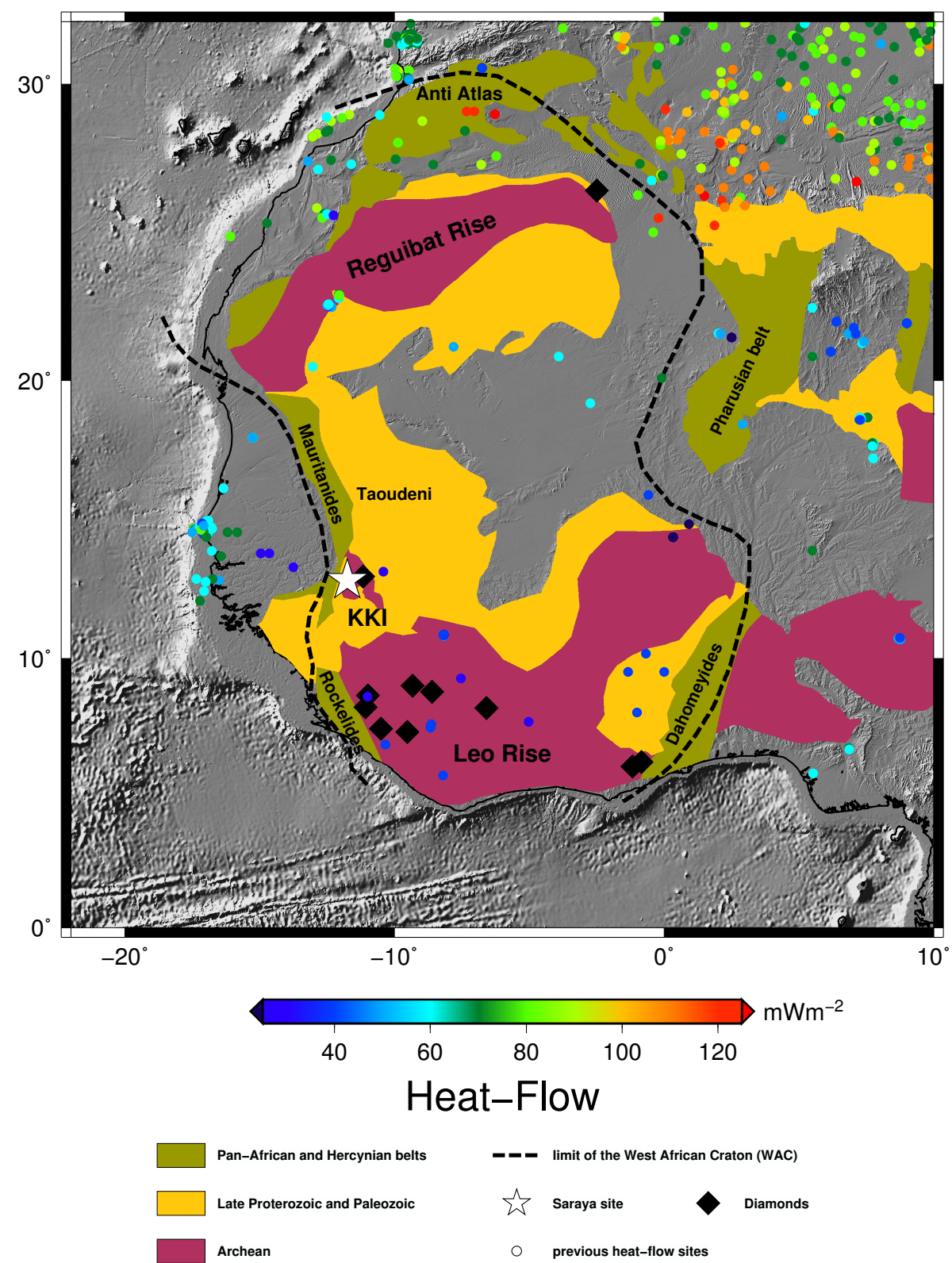

Fig. 1. Location of the Saraya site in the Kédougou Kénieba Inlier (KKI). The main geological units are reported from Gueye et al. (2007) and the heat-flow data from an updated version of the global heat-flow database (Goutorbe et al., 2011).

a site in the West African Craton (WAC) and also in the Sahel domain, which represents the transition between arid and sub-humid climatic conditions. Although these measurements have been obtained in nearby boreholes, they show differences in the upper $100 \mathrm{~m}$ for which we examine the possible causes in order to obtain reliable estimates of both the surface heat-flow and of the past temperature history.

\section{Geological context}

The heat-flow measurements are located near the village of Saraya, at the south-eastern border of Senegal (Fig. 1). This region belongs to the Kédougou Kénieba Inlier (KKI) in the WAC, limited by the Pan-African belt (Mauritanides) on the western side and the Phanerozoic sediments of the Taoudeni basin on the eastern side. The KKI consists of Early Paleo-Proterozoic terranes (Birimian) formed during the Eburnean orogeny from $\sim 2200-2000 \mathrm{Myr}$ and is composed of a volcano-sedimentary greenstone belt intruded by calcalkaline granites. Early Proterozoic kimberlitic pipes intrude 
the Biriminan terranes in the southern part of the WAC, including the Kedougou-Kenieba region where they could be early Cretaceous (Michel, 1996). The Saraya batholith is one of these granitic intrusions as large as $2000 \mathrm{~km}^{2}$ formed at about $2079 \mathrm{Myr}$ (Gueye et al., 2007). In the area of the heatflow measurements, it is a two micas syenitic granite with pegmatite equivalents composed of coarse grains with 23 32 percent of quartz, 47-62 percent of microcline (potassic feldspar), 10-15 percent of plagioclase, 1-2 percent of muscovite and 1-2 percent of biotite (Ndiaye, 1994). The upper $20-30 \mathrm{~m}$ is formed by saprolithes (laterite, lithomarge and granitic sands from the top to the bottom), which represents the alteration products of granites in a tropical context (Diouf, 1999). The water level is generally shallow (less than $10 \mathrm{~m}$ when we did measurements) and the granitic sands above the fresh granite can locally form good aquifers (Diouf, 1999).

\section{Previous heat-flow measurements}

Only few heat-flow measurements are available in the WAC (Fig. 1). The first measurements in the southern part (Leo Rise) revealed low values (Chapman and Pollack, 1974; Beck and Mustonen, 1972) confirmed by later measurements (Sass and Behrendt, 1980; Brigaud et al., 1985). Measurements in the northern part of the WAC (Brigaud et al., 1985; Rimi and Lucazeau, 1987; Lesquer et al., 1989; Takherist and Lesquer, 1989; Lesquer et al., 1991) have conversely shown values $15-20 \mathrm{~mW} \mathrm{~m}^{-2}$ higher. The Pan-African border also shows higher values in the north (Brigaud et al., 1985; Rimi and Lucazeau, 1987; Latil-Brun and Lucazeau, 1988; Lesquer et al., 1989; Takherist and Lesquer, 1989) than the western border (Latil-Brun and Lucazeau, 1988; Lesquer et al., 1991). Lesquer and Vasseur (1992) have correlated the higher heat-flow in the north to the presence of a regional mantle anomaly that also affects the large scale gravity field and the P-waves propagation.

\section{Climatic context}

The Senegal climate is at the transition between arid to hyperarid (Sahara desert) in the north of Senegal and dry subhumid in the south. This transition zone is known as the Sahel that runs from Senegal to Ethiopia. The Sahel climate is basically controlled by the intertropical convergence zone (ITCZ), which determines the dry season (NovemberApril) when it migrates southward and the wet season (MayOctober) when the monsoon winds flow from the Atlantic. The air temperature varies according to these seasons, with higher values and smaller amplitude during the dry season (Fall et al., 2006). Several meteorological stations have recorded temperatures since the mid 20th century, and the average annual temperature evolution shows a significant increase, mostly caused by the increase during the dry sea-
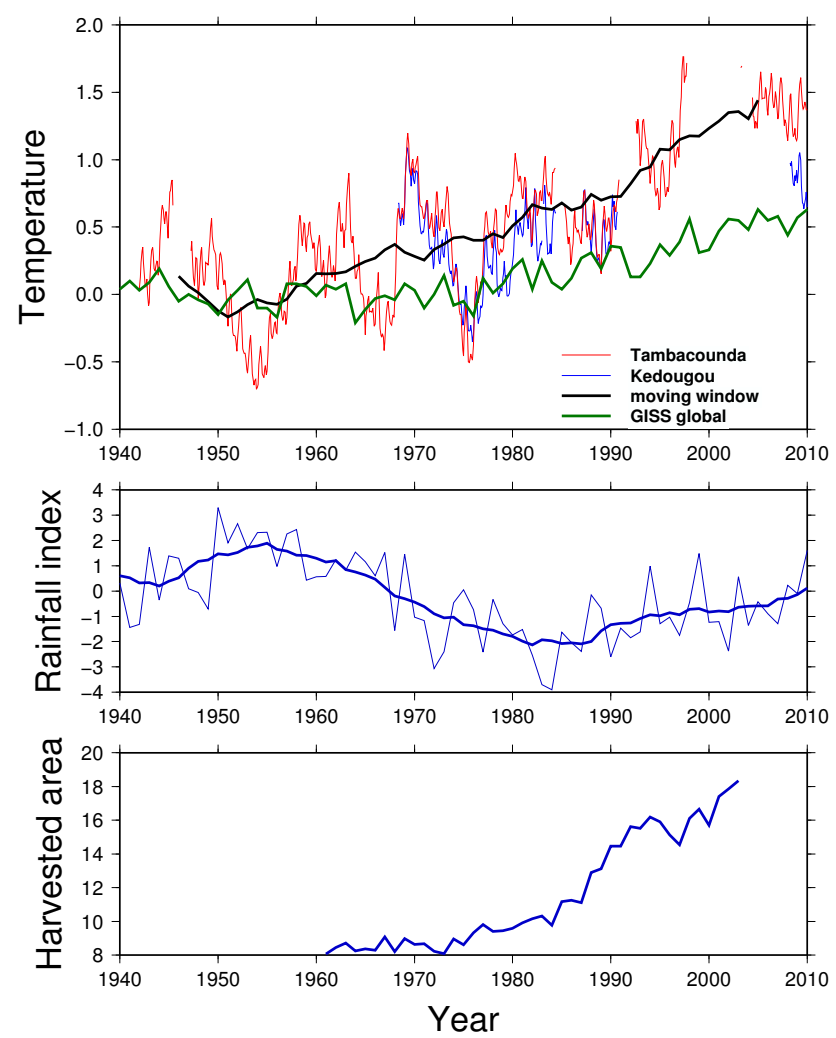

Fig. 2. Upper part: 2 and 10 years running average air temperatures at the meteorological stations of Tambacounda and Kedougou. The world annual average from the Goddard Institute for Space Studies (http://data.giss.nasa.gov/gistemp/graphs/Fig.A2.txt) is also shown. Middle part: Sahel precipitations ( $\mathrm{cm} / \mathrm{month})$ from NOAA NCDC (http://jisao.washington.edu/data/sahel/). The thick line is a 10 years moving window. Lower part: Area $\left(10^{6}\right.$ ha) devoted to crops in the Sahel since 1960 (Kandji et al., 2006).

son in the western part of Senegal (Fall et al., 2006). We have analysed the trend of the air temperature at the Kedougou and Tambacounda meteorological stations (the closest from the site of Saraya). The Tambacounda station has almost a continuous record since 1941, while the Kedougou station starts only in 1967 and has many gaps. We filtered the monthly averages (obtained at http://data.giss.nasa.gov/ gistemp/station_data/) with a 2 years and a 10 years running window (Fig. 2), which shows a linear increasing trend of about $0.0215^{\circ} \mathrm{C} \mathrm{yr}^{-1}$ since the beginning of the instrumental record. This trend is less important than in the Western part of Senegal (Fall et al., 2006), but more important than the world average for the same period of time (Fig. 2).

The Sahel zone was also strongly affected in the 1960 s by desertification and starvation following the increasing dryness and overuse of agriculture capacities (Zeng, 2003). The increase of SAT in eastern Senegal correlates well with the decrease in precipitation as well as the increase of agricultural activity (Fig. 2). The relative importance of the forcing factors (human misuse of the land or climatic changes) has 


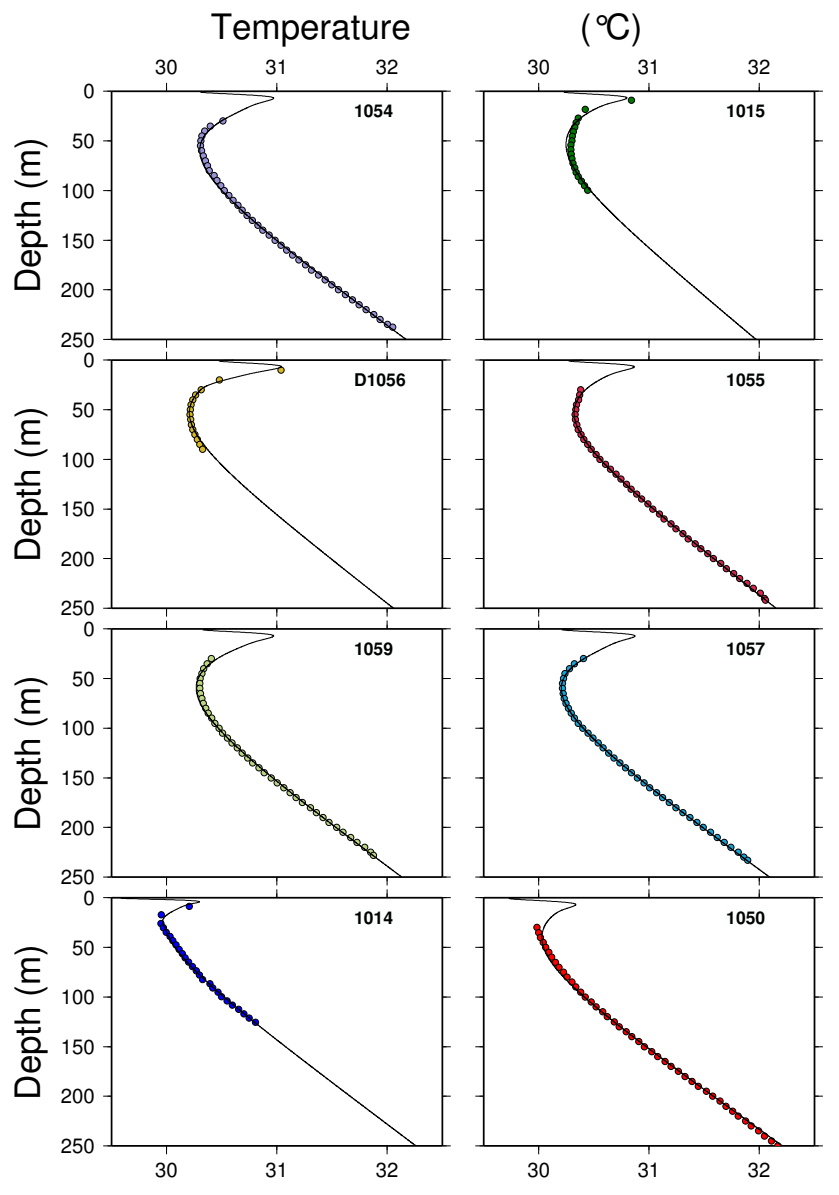

Fig. 3. Temperature versus depth profiles. Circles are measurements, thin lines are results of the numerical model including both the variations of surface temperature and the site effects. Parameters of the models are specified in Table 2 (see also discussion section).

long been debated, but some recent models (Giannini et al., 2003) primarily related the southward shift of the ITCZ to the increasing sea surface temperatures in the Atlantic and the positive land-atmosphere feedback. Because of this shift, the region of Saraya, which was sub-humid in the 1960s, is now in a semi-arid condition (Fall et al., 2006; Lebel and Ali, 2009). Additionally, the long-term temperatures recorded by few meteorological stations in the Sahel are weakly but inversely correlated to the rainfall index (Hulme et al., 2001).

During the Last Glacial Maximum (23-18 ka BP), the climate was dry and cooler than today (Gasse, 2000). The transition to the interglacial started at $17 \mathrm{ka} \mathrm{BP}$, followed by a wet period (African Humid Period) from 14.8 to $5.5 \mathrm{ka}$ BP (deMenocal et al., 2000): the Sahel and the Sahara regions were covered at that time by lakes and wetlands (Lézine et al., 2011). The SAT was about $3{ }^{\circ} \mathrm{C}$ lower than today during the Late Glacial Maximum (Gasse et al., 2008) and about $1{ }^{\circ} \mathrm{C}$ lower during the African Humid Period (Patricola and Cook, 2007).
Table 1. Thermal conductivity measured at site 1054

\begin{tabular}{ccc}
\hline Depth $(\mathrm{m})$ & Thermal conductivity $\left(\mathrm{W} \mathrm{m}^{-1} \mathrm{~K}^{-1}\right)$ & (s.d.) \\
\hline 124.00 & 2.61 & 0.05 \\
141.55 & 2.78 & 0.05 \\
160.50 & 2.97 & 0.05 \\
182.40 & 2.22 & 0.02 \\
204.50 & 2.66 & 0.08 \\
218.90 & 2.75 & 0.06 \\
243.00 & 2.62 & 0.06 \\
\hline
\end{tabular}

\section{Borehole temperature measurements at Saraya}

The temperature measurements (Fig. 3) have been obtained in 8 mining exploration boreholes near the village of Saraya. The temperature was determined with a thermistor probe calibrated in the laboratory with a better than $0.005 \mathrm{~K}$ accuracy. Measurements were recorded at $5 \mathrm{~m}$ deep intervals. We initially started temperature measurements at a $30 \mathrm{~m}$ depth (the base of the alteration zone), but later we recorded from $10 \mathrm{~m}$ in order to better constrain the climatic signal, as the water level was around 6-8 $\mathrm{m}$ when we did the measurements. The bottom of the measurements is generally between 230 $250 \mathrm{~m}$, but in few of them it was not possible to log below the tubed part $(100 \mathrm{~m})$. The temperatures and temperature gradients are very similar in the deep part (depth $>125 \mathrm{~m}$ ), but differ significantly in the upper hundred metres.

\section{Rocks thermal conductivity}

Thermal conductivity was measured on cores by a divided bar method (Misener and Beck, 1960) at the IPGP geothermal laboratory. Only one (1054) of the boreholes where we obtained temperature measurements was cored and, therefore, only this one was sampled at $20 \mathrm{~m}$ intervals from $125 \mathrm{~m}$ to $245 \mathrm{~m}$. A single conductivity determination with the divided bar method relies on five measurements at steady-state, obtained on five different water-saturated plugs with thickness varying from $2 \mathrm{~mm}$ to $10 \mathrm{~mm}$. The thermal resistance of each plug is measured and the thermal conductivity is calculated by a least-squares linear fit to the resistance/thickness data. This procedure allows the detection of sample-scale variations of mineralogy unrepresentative of the large-scale average rock composition. It also eliminates isolated heterogeneities and yields a truly representative conductivity that characterises large-scale crustal heat conduction. The accuracy of the measurement is better than 3 percent (Mareschal et al., 2005).

The thermal conductivity (Table 1) is homogeneous in the lower part of the borehole $\left(2.66,2.75\right.$ and $2.62 \mathrm{~W} \mathrm{~m}^{-1} \mathrm{~K}^{-1}$ at $205 \mathrm{~m}, 219 \mathrm{~m}$ and $243 \mathrm{~m}$, respectively). At $182 \mathrm{~m}$, thermal conductivity is significantly lower $\left(2.22 \mathrm{~W} \mathrm{~m}^{-1} \mathrm{~K}^{-1}\right)$, and then higher $\left(2.97\right.$ and $\left.2.78 \mathrm{~W} \mathrm{~m}^{-1} \mathrm{~K}^{-1}\right)$ at $160 \mathrm{~m}$ and 
$142 \mathrm{~m}$, respectively. The last core at $124 \mathrm{~m}$ gives a value of $2.61 \mathrm{~W} \mathrm{~m}^{-1} \mathrm{~K}^{-1}$. This represents large variations, but not exceptional for granites, which can be partly attributed to some changes in the mineralogy (less quartz and more feldspar at $182 \mathrm{~m}$ and $124 \mathrm{~m}$ ). The higher thermal conductivity at $142 \mathrm{~m}$ and $160 \mathrm{~m}$ is correlated with a lower temperature gradient, insuring a constant heat-flow. At $124 \mathrm{~m}$, the low temperature gradient $\left(8.4 \mathrm{~m} \mathrm{Km}^{-1}\right)$ is still influenced by the climatic signal, which explains the absence of correlation with the thermal conductivity. Finally, only one conductivity measurement $(182 \mathrm{~m})$ remains unexplained and we assumed that it is not representative of the overall thermal structure. We assumed, therefore, that $2.66 \mathrm{~W} \mathrm{~m}^{-1} \mathrm{~K}^{-1}$ is representative of the thermal conductivity of the Saraya granite, as it represents both the average of all the measurements as well as the value in the deepest part of the borehole (more than $200 \mathrm{~m}$ ) where the thermal gradient is not affected by the superficial perturbations.

\section{Ground temperature history}

The past temperature variations on the surface of the Earth are recorded as perturbations in the subsurface temperature gradient (Birch, 1948). The depth at which the perturbations are filtered out ("thermal length") depends on the wavelength of the climatic fluctuations (about $50 \mathrm{~cm}$ and $10 \mathrm{~m}$ for daily and annual variations). For the temperature anomalies recorded in the Saraya boreholes (order of $120 \mathrm{~m}$ ), one can expect that the surface temperature was perturbed for a period of about $100 \mathrm{yr}$ before measurements. On the other hand, perturbations related to the Last Glacial Maximum (23-18 ka BP) or the African Humid Period (14.8-5.5 ka BP) cannot be detect in this depth range. This can affect the determination of surface heat-flow for high latitudes (Vasseur and Lucazeau, 1983; Rath et al., 2012), but remains negligible in African tropics (less than $3 \mathrm{~mW} \mathrm{~m}^{-2}$ ).

Several previous studies provided algorithms to estimate the ground surface temperature history from the temperatures anomalies measured in boreholes. We used the singular value decomposition (SVD) inversion method developed by Mareschal and Beltrami (1992). In this method, the subsurface temperature distribution is considered as the sum of a stationary component resulting from the background heatflow $q_{0}$ and a transient perturbation $T_{\mathrm{t}}(z, t)$ due to the propagation of the seasonal and paleoclimatic fluctuations at the surface:

$T(z, t)=T_{0}+\frac{q_{0} z}{\lambda}+T_{\mathrm{t}}(z, t)$

The GST history is discretised as a succession of surface temperature step changes $T_{j}^{G}$ at time $t_{j}$ before the present-time $(t=0)$ and the transient perturbation is:

$T_{\mathrm{t}}(z, t)=\sum_{j=1}^{N} T_{j}^{G}\left(\operatorname{erfc}\left(\frac{z}{2 \sqrt{\kappa t_{j}}}\right)-\operatorname{erfc}\left(\frac{z}{2 \sqrt{\kappa t_{j-1}}}\right)\right)$
As the temperature is measured at several depths $z_{i}, i=1, m$, a set of $m$ linear equations can be formed from Eq. (1) and inverted for the unknown variables $T_{0}, q_{0}$ and $T_{t}(z, t)$. In order to limit the numerical instabilities, the method used a regularisation parameter, which can be either a cutoff of the lowest singular values or a damping parameter added to them. We used the second method that gives better results for our problem. Because of the shallow depths of the boreholes, we have also limited the reconstruction to a period of 310 years before 2010 (date of the measurements). In order to find the optimal value of the damping parameter $f$, we used a similar "Lcurve" method as Hartmann and Rath (2005), which corresponds to the plot of the $L_{2}$ norm of the data misfit as a function of the $L_{2}$ norm of the model. The optimal value $f$ corresponds to the corner of the "L-curve" where the data misfit and the model oscillations are minimum. As shown in Fig. 4, the optimal f-value depends on the noise level and is not the same for all boreholes ( $f=0.05$ for hole $1059, f=0.01$ for hole 1054 and $f=0.001$ for hole 1057). We used $f=0.01$, which is more appropriate for the whole dataset. The time discretisation of the model has also an important effect on the reconstructed GST. We have tested different values for borehole 1057, where the site effects are probably not important (see below). The best fit was obtained for 100 time steps over the period 1700-2010.

If we apply the same discretisation $(n=100)$ and the same damping value ( $f=0.01)$ for all boreholes (Fig. 5), we obtain a consistent pattern with a small temperature increase $\left(0.2-0.4^{\circ} \mathrm{C}\right)$ between 1700 and 1940 , and then a faster increase $\left(1.0-2.0^{\circ} \mathrm{C}\right)$ from 1940 to 2000 . Several boreholes $(1054,1057,1059$ and 1055) are consistent with the trend of SAT measured at Tambacounda, others show higher (D1056, $1015)$ or lower $(1050,1014)$ amplitudes. We assumed, therefore, that the GST that deviate too much are affected by site effects and we developed a method to also account for these effects in the reconstruction of the past temperature.

\subsection{Site effects}

Different causes have been invoked to explain such effects: urbanisation, landscape or subsurface changes can affect the climatic signal recorded in boreholes. In Canada, the variable snow cover can control the relation between the air temperature and the ground temperature (Mareschal and Beltrami, 1992). In central Africa, the deforestation before mining exploration has probably caused the local increase of the GST (Sebagenzi et al., 1992). The local effects of hydrology and/or thermal conductivity can also be important according to the repeated borehole temperature measurements in the Netherlands (Kooi, 2008). At the site of Saraya, boreholes are very close each other (100 to $700 \mathrm{~m}$ ) except D1056, which is $5 \mathrm{~km}$ away, surface conditions are similar (savanna) with no known recent change. It is more likely that the observed differences are related to subsurface conditions that can change with the local characteristics of the 

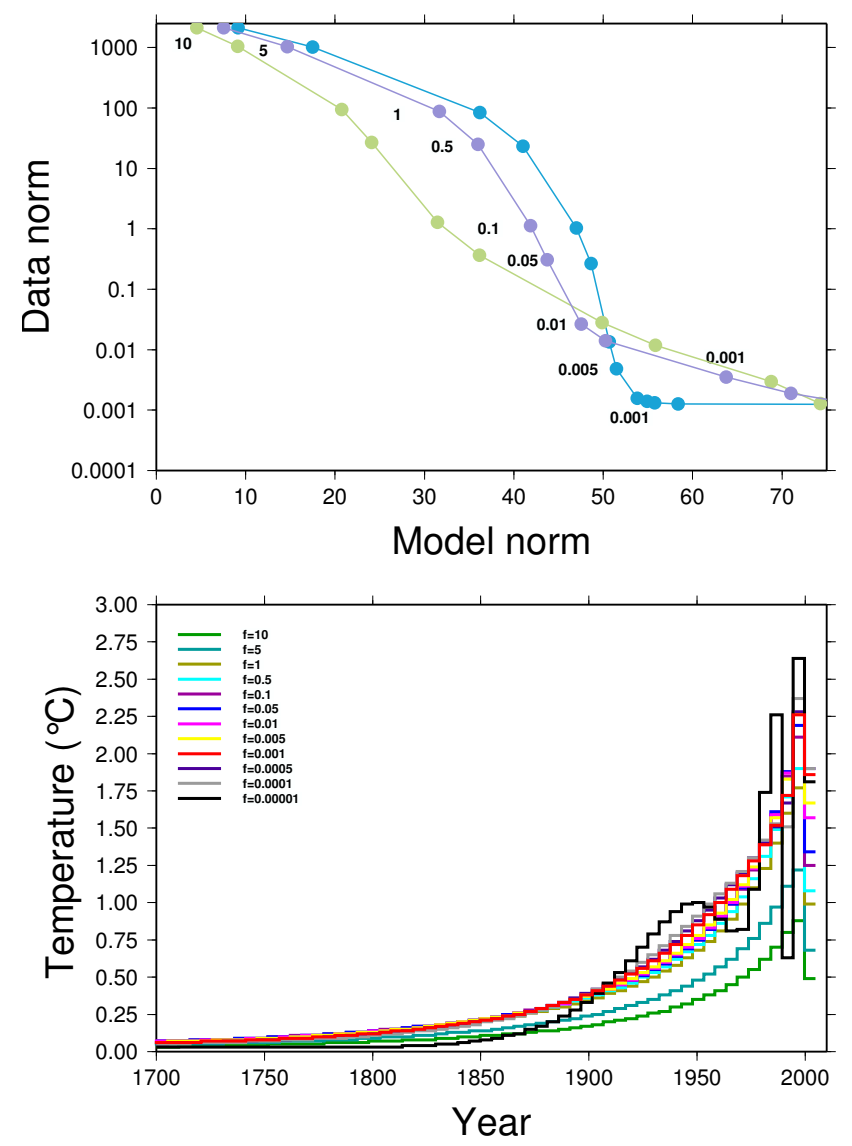

Fig. 4. Optimisation of the regularisation factor $f$ in the SVD inversion. Lower part: GST for different values of the regularisation factor $f$ (inversion for hole 1057). Upper part: L-curves for boreholes 1057 (blue), 1054 (violet) and 1059 (green).

alteration domain (about $30 \mathrm{~m}$ below the surface). This alteration domain is generally formed by laterites in the uppermost part which evolve progressively to highly permeable granitic sands at the contact with fresh granite (Diouf, 1999). Thermal conductivity of the laterites is very low (0.5$1.15 \mathrm{~W} \mathrm{~m}^{-1} \mathrm{~K}^{-1}$ according to Meukam et al., 2004), and because their porosity can be locally high (up to 50 percent according to Diouf, 1999, p. 52), the thermal conductivity of granitic sands can also be low (water filling the pores has a low thermal conductivity). Permanent circulations of fluids are also possible in the porous and unconsolidated granitic sands, which can also affect the propagation of the climatic signal in the ground. We assume that water recharges somewhere at the surface and flows downward rapidly to the aquifer at a depth of $20-30 \mathrm{~m}$, then flows horizontally in this aquifer cooling the host rock and finally flows upward to the surface (Fig. 6). In order to test these different effects, we built a 1-D finite differences model that includes the effect of the surface temperature variations at the upper boundary condition and the effect of vertical or horizontal fluid circulations in a superficial aquifer. We considered three types of

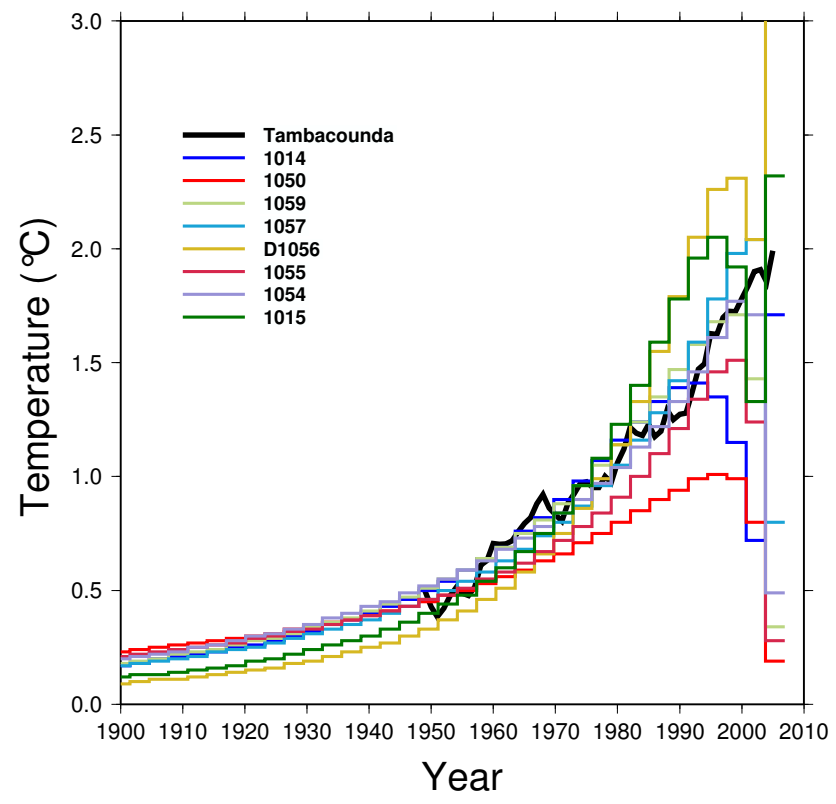

Fig. 5. Ground surface temperature history inverted at each borehole compared to the trend at the Tambacounda meteorological station. The decrease observed after year 2000 in several boreholes is an artefact of the inversion when the upper $30 \mathrm{~m}$ are not constrained by data (this does not appear for boreholes where we measured temperature between 10 and $30 \mathrm{~m}$, which show higher temperature increases). On the other hand, boreholes 1014 and 1050 show lower temperature increases.

perturbations in the upper part of the boreholes (lower conductivity $\lambda_{\mathrm{a}}$ in the alteration zone, horizontal circulation of meteoric fluids at a velocity $V_{\mathrm{h}}$ and/or vertical circulation at a velocity $V_{\mathrm{w}}$ in the aquifer at the bottom of the alteration domain). The surface temperature variations with time have been fixed at the same values (those recorded at the Tabacounda meteorological station) for all boreholes, but the average value $T_{\mathrm{S}}$ as well as the local heat-flow $q_{0}$ can be adjusted separately. There are, therefore, five parameters $\left(\lambda_{\mathrm{a}}\right.$, $V_{\mathrm{h}}, V_{\mathrm{w}}, T_{\mathrm{s}}$ and $q_{0}$ ) that are inverted by a Monte-Carlo procedure to minimise the RMS difference between observed and calculated temperatures at depth.

\subsection{Monte Carlo inversion}

The Monte-Carlo inversion is based on the forward resolution of the 1-D heat equation with advection of fluids and heat production:

$\rho_{b} c_{b} \frac{\partial T}{\partial t}=\frac{\partial}{\partial z}\left(\lambda_{\mathrm{b}} \frac{\partial T}{\partial z}\right)+A_{\mathrm{b}}+A_{\mathrm{w}}+\rho_{\mathrm{w}} c_{\mathrm{w}} V_{\mathrm{w}} \frac{\partial T}{\partial z}$

where $\lambda_{\mathrm{b}}, \rho_{\mathrm{b}}, c_{\mathrm{b}}$ and $A_{\mathrm{b}}$ are, respectively, the bulk thermal conductivity, density, specific heat and heat production of the host rock. 


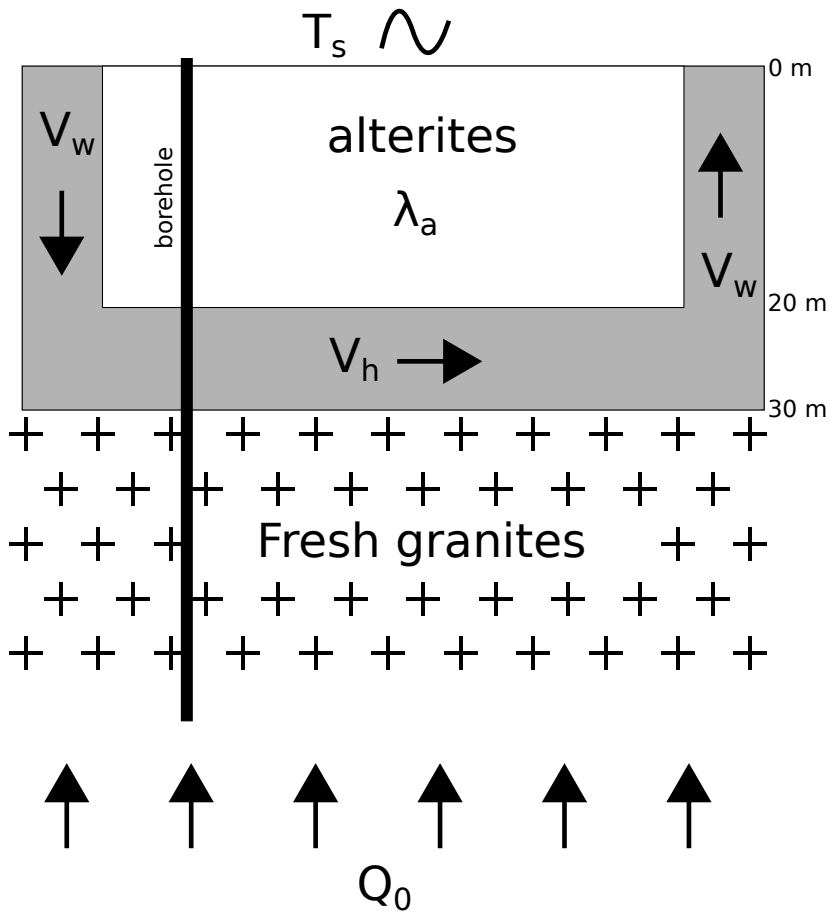

Fig. 6. Conceptual model of perturbations that affect the temperature field at Saraya. The background heat-flow $q_{0}$ controls the normal temperature gradient. Perturbations are related to the variation of the surface temperature with time, the fluid circulations in permeable zones (characterised by Darcy velocities $V_{\mathrm{w}}$ and $V_{\mathrm{h}}$ ) and/or the low thermal conductivity (diffusivity) $\lambda_{\mathrm{a}}$ in the alteration zone (0-30 m).

$\rho_{\mathrm{w}}$ and $c_{\mathrm{W}}$ are, respectively, the bulk density and specific heat of water. $V_{\mathrm{w}}$ is the vertical circulation of the fluid. $A_{\mathrm{w}}$ is a heat sink accounting for the horizontal fluid circulation.

The equation is solved by an implicit finite differences method. The mesh is divided into 2500 cells of $0.1 \mathrm{~m}$ and the time step is 0.0833 year. The upper boundary condition is fixed as $T_{\mathrm{S}}+\Delta T_{\mathrm{S}}(t)$ where $\Delta T_{\mathrm{S}}(t)$ is the temperature anomaly monthly recorded at the Tambacounda station extrapolated in the past from the SVD inversion for $n=100\left(0.4{ }^{\circ} \mathrm{C}\right.$ from 1700 to 1940 . This value also gives the best results for the Monte-Carlo procedure). The lower boundary condition is the background heat-flow $q_{0}$.

The Monte-Carlo inversion involves an a priori Gaussian distribution of the parameter range and a set of 10000 iterations.

The quality of results is estimated by the total RMS defined by:

$\mathrm{RMS}=\sqrt{\frac{1}{n} \sum_{i=1}^{n}\left(T_{\mathrm{obs}}^{i}-T_{\mathrm{calc}}^{i}\right)^{2}}$

where $n$ is the number of temperatures measured in the borehole. The best solution obtained for the lowest value of the

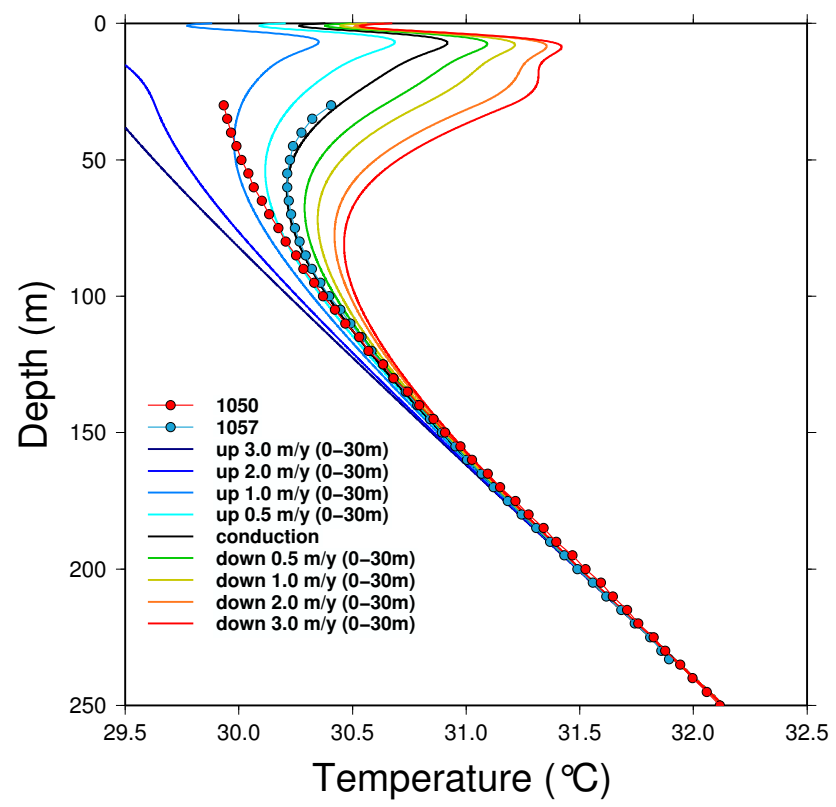

Fig. 7. Temperature $\operatorname{logs}$ at 1050 and 1057 compared to model results including the surface temperature variations recorded at the Tambacounda meteorological station and a vertical fluid circulation in the alteration zone $(0-30 \mathrm{~m})$.

RMS is given in Table 2 and in Fig. 3 for all the Saraya boreholes.

\subsection{Vertical fluid flow in the alteration zone}

The climatic perturbations can be amplified (or reduced) by vertical downward (upward) fluid circulations (Kooi, 2008). We have tested several models including climatic fluctuations at the surface and vertical fluid flow that corresponds to recharging or discharging zone (between the surface and the top of fresh granites). The models assume that the fluid flow started long before the climatic variations at the surface and, therefore, the initial conditions include the effect of a permanent flow. Some results with vertical fluid circulations are shown in Fig. 7: as expected, the downward flow increases the climatic perturbation while the upward flow reduces it. The best model for borehole 1057 is the pure conductive assumption, while borehole 1050 requires an upward vertical velocity of $\sim 1 \mathrm{~m} \mathrm{yr}^{-1}$ in the range $0-30 \mathrm{~m}$. This would correspond to the discharge part of the circulation (Fig. 6).

\subsection{Horizontal fluid flow in the alteration zone}

Assuming that superficial aquifers are part of a system where meteoric fluids recharge at the surface, a permanent horizontal circulation can remove some of the conductive vertical heat-flow and, therefore, limit the propagation of the climatic wave to the depth. In order to estimate how much fluid flow is required, we assumed that this effect is equivalent to a heat sink proportional to the difference between the 
Table 2. Heat-flow and temperature gradient at the site of Saraya. (1) Borehole number; (2) longitude; (3) latitude; (4) measurement depth range $(\mathrm{m}) ;(5)$ temperature gradient $\left(\mathrm{m} \mathrm{Km}^{-1}\right)$ in the lower part of the borehole; (6) heat-flow $\left(\mathrm{mW} \mathrm{m}^{-2}\right)$ resulting from the Monte Carlo inversion; (7) reference surface temperature $\left({ }^{\circ} \mathrm{C}\right)$; (8) thermal conductivity in the alteration zone $(0-30 \mathrm{~m})\left(\mathrm{W} \mathrm{m}^{-1} \mathrm{~K}^{-1}\right)$; (9) horizontal fluid

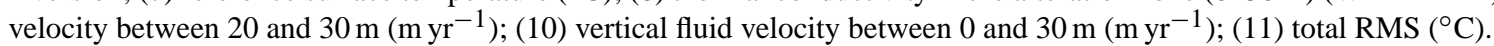

\begin{tabular}{lrrrrrrrrrr}
\hline$(1)$ & $(2)$ & $(3)$ & $(4)$ & $(5)$ & $(6)$ & $(7)$ & $(8)$ & $(9)$ & $(10)$ & $(11)$ \\
\hline 1054 & -11.75585 & 12.84058 & $30-235$ & 11.94 & 32.1 & 29.10 & 2.51 & 0.0 & 0.0 & 0.0198 \\
1057 & -11.75506 & 12.84041 & $30-235$ & 12.19 & 32.5 & 29.00 & 2.65 & 0.0 & 0.0 & 0.0094 \\
1059 & -11.75522 & 12.84144 & $30-225$ & 12.04 & 31.9 & 29.12 & 2.65 & 0.006 & 0.0 & 0.0185 \\
1055 & -11.75474 & 12.84882 & $30-240$ & 12.61 & 30.7 & 29.34 & 2.65 & 0.035 & 0.0 & 0.0109 \\
1050 & -11.75474 & 12.84882 & $30-235$ & 12.61 & 33.3 & 28.51 & 2.65 & 0.0 & -1.04 & 0.0223 \\
D1056 & -11.72043 & 12.87992 & $10-90$ & 16.47 & 30.3 & 29.28 & 2.65 & 0.045 & 0.0 & 0.0353 \\
1014 & -11.75387 & 12.84637 & $10-145$ & 15.57 & 31.0 & 28.15 & 2.65 & 0.0 & -1.59 & 0.0199 \\
1015 & -11.75784 & 12.84575 & $10-110$ & 13.74 & 28.5 & 29.02 & 2.65 & 0.0 & -0.69 & 0.0321 \\
\hline
\end{tabular}

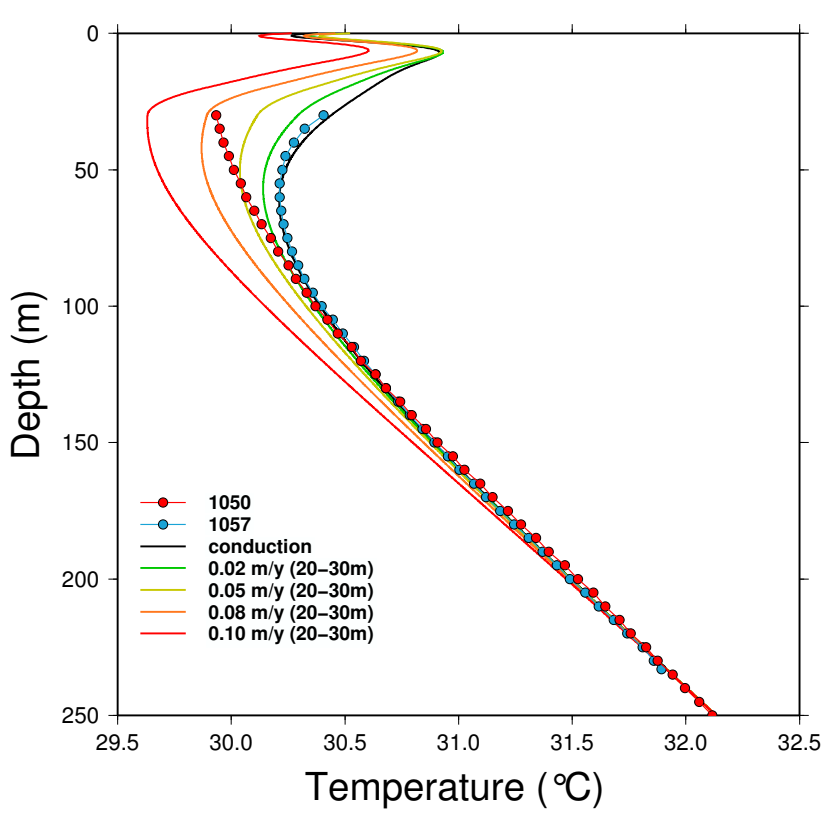

Fig. 8. Temperature logs at 1050 and 1057 compared to model results including the surface temperature variations recorded at the Tambacounda meteorological station and the horizontal fluid circulation in an aquifer between 20 and $30 \mathrm{~m}$.

rock temperature $T_{\mathrm{r}}$ and the fluid temperature $T_{\mathrm{f}}$, and to the fluid velocity $V_{\mathrm{h}}$ :

$\rho_{\mathrm{w}} c_{\mathrm{w}} V_{\mathrm{h}}\left(T_{\mathrm{r}}-T_{\mathrm{f}}\right)$

where $\rho_{\mathrm{w}}$ and $c_{\mathrm{w}}$ are the density and specific heat of the fluid. In a first approximation, we assume that the temperature of the fluid equals the temperature $T_{\mathrm{S}}$ at the surface and that the permeable zone where fluids can flow is located between 20 and $30 \mathrm{~m}$. Some results are shown in Fig. 8 and compared to the observations of two temperature profiles at boreholes 1057 and 1050. The temperature profile in the first one is best explained by pure conduction, while it requires
$0.05 \mathrm{~m} \mathrm{yr}^{-1}$ to explain the attenuation of the upper temperature anomaly in borehole 1050.

\subsection{Low thermal conductivity in the alteration zone}

Similarly, we have tested the effect of low conductivity (between 1 to $\left.2 \mathrm{~W} \mathrm{~m}^{-1} \mathrm{~K}^{-1}\right)$ in the alteration zone $(0-30 \mathrm{~m})$ with respect to the standard "normal" value of granites $\left(2.65 \mathrm{~W} \mathrm{~m}^{-1} \mathrm{~K}^{-1}\right)$. Figure 9 shows that the lower the conductivity in the alteration zone, the lower the apparent climatic perturbation in the borehole. The best value of the thermal conductivity to explain the temperature profiles at boreholes 1050 is $1.25-1.50 \mathrm{~W} \mathrm{~m}^{-1} \mathrm{~K}^{-1}$. This is a likely value for granitic sands with $40-50$ percent porosity as well as for laterite (Meukam et al., 2004).

\section{Discussion}

\subsection{Origin of the local anomalies}

The temperature profiles in the eight boreholes at the site of Saraya are all affected by the surface air temperature increase during the twentieth century, but they do not all record the same amplitude of this increase. Two boreholes (1050 and 1014) show a lower perturbation than the others. Because all of these boreholes are very close to each other and because there is no obvious change of the local surface conditions, we have attributed the causes of these differences to the subsurface conditions and more specifically to the nature of the alteration zone. The drilling record mentions, for instance, difficulties at site 1050 related to the stability of the saprolith and one other borehole was totally collapsed during our visit. The base of the alteration zone is formed by coarse grains granitic sands, which can be local aquifers. We have no details on the exact nature of this saprolith, but we did simple numerical models including either the changes that can affect the conductive structure (high porosity decreases thermal conductivity significantly) or the circulation of fluids. The observed temperature profiles can be generally explained 


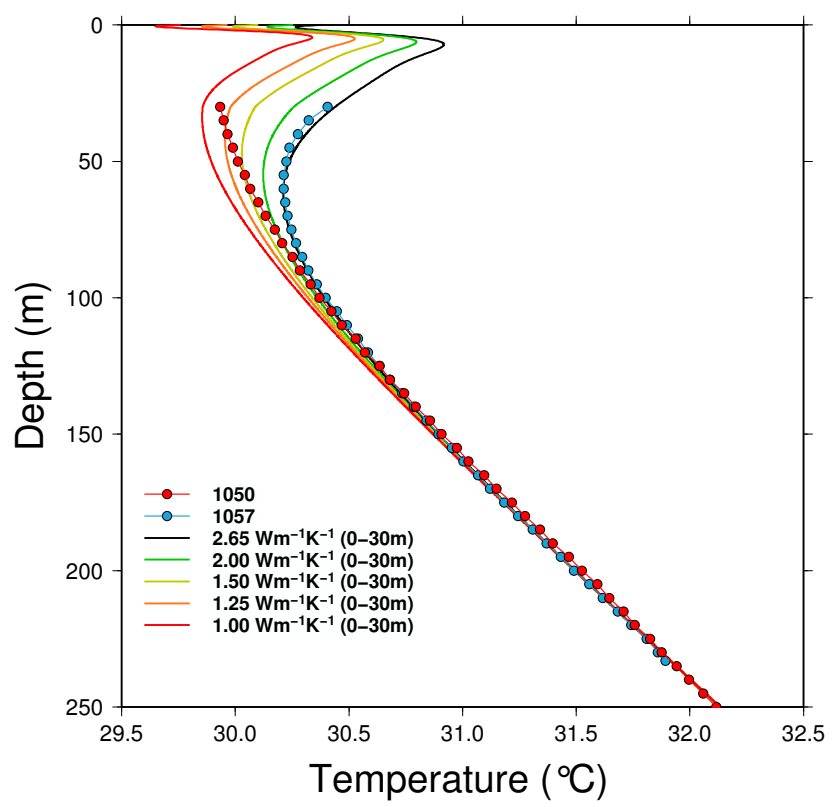

Fig. 9. Temperature logs at 1050 and 1057 compared to model results including the surface temperature variations recorded at the Tambacounda meteorological station and a low thermal conductivity in the laterite and saprolithe between 0 and $30 \mathrm{~m}$.

by several different processes or combinations of these processes (vertical, horizontal fluid flow or thermal conductivity). The best model is not necessarily the only way to explain the observations: for instance, we interpret the temperature profiles at sites 1050 and 1014 by vertical fluid circulations, but they could also be explained by the presence of low thermal conductivity rocks $\sim 1 \mathrm{~W} \mathrm{~m}^{-1} \mathrm{~K}^{-1}$.

The reference surface temperature inferred from the boreholes is $29.0 \pm 0.3^{\circ} \mathrm{C}$, which gives a GST of $28.6^{\circ} \mathrm{C}$ in 1940 . This is only $0.3{ }^{\circ} \mathrm{C}$ more than the SAT recorded at Tambacounda. As this meteorological station is more than $100 \mathrm{~km}$ away, it is, however, difficult to assess that GST and SAT are almost equal in this region and it could be only fortuitous.

\subsection{Past surface temperature history in West Africa}

The recent increase of GST observed at Saraya has not been described before. The only other data published in this part of Africa have been obtained in Niger by Chapman and Pollack (1974) and the GST history available on line (http://www.ncdc.noaa.gov/paleo/borehole/ reconstruction/ne-k6b.html and http://www.ncdc.noaa.gov/ paleo/borehole/reconstruction/ne-donkolo4.html) has been analysed by Huang et al. (2000). The temperatures in these boreholes have been recorded in 1972 only from the depth of $50 \mathrm{~m}$ (Donkolo) and $80 \mathrm{~m}$ (Kourki K6B). Therefore, the GST does not catch the increase of temperature in the midtwentieth century (Fig. 10), but the trend before is not very different from that obtained at Saraya.
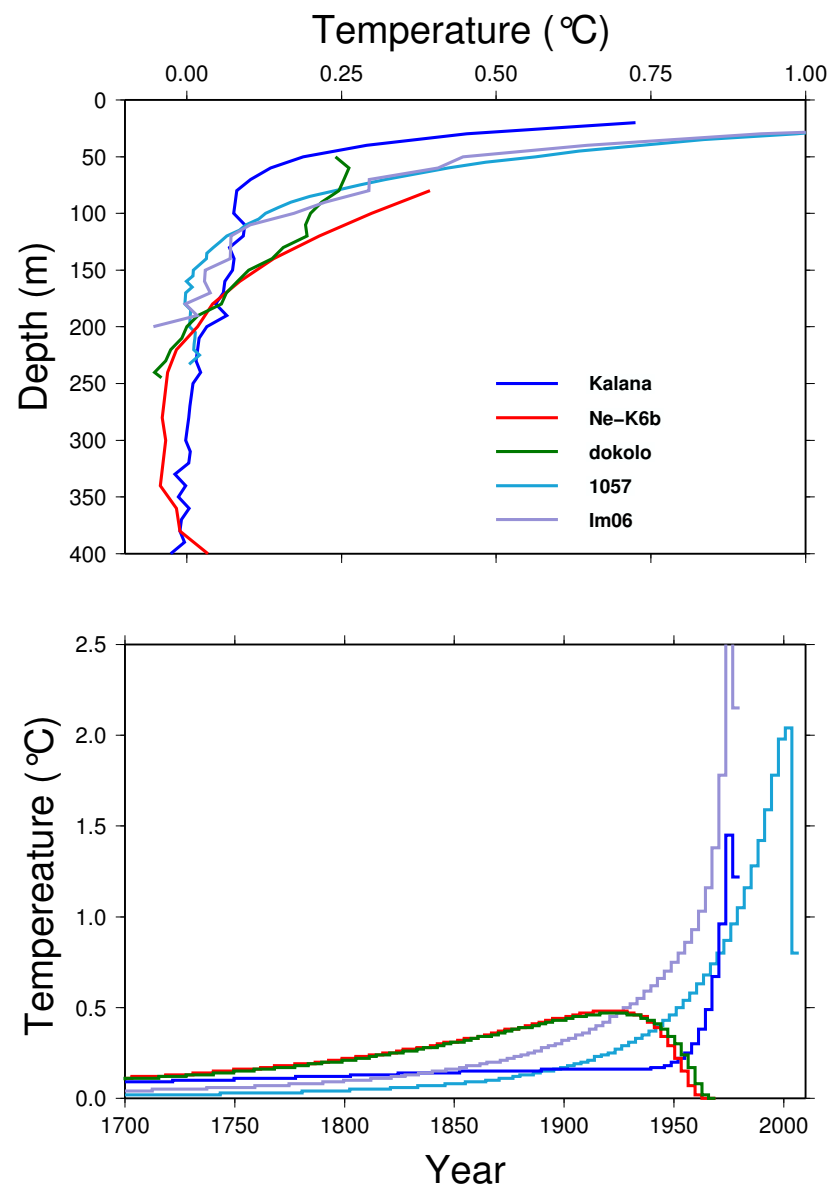

Fig. 10. Comparison of the ground surface temperature from boreholes data in West Africa. Upper part: temperature offset from the linear gradient; lower part: ground surface temperature history. Data from Huang et al. (2000) at sites Ne-K6b and Donkolo have been reinterpreted with the same procedure as other boreholes.

We have also processed the temperature measurements acquired in March 1983 in two boreholes in Mali (Brigaud et al., 1985). The upper part of the temperature profiles show a gradient inversion similar to that observed at Saraya. The GST history, obtained by SVD inversion with the same parameter values, leads to the same previous conclusions: there is no major change of the surface temperature before the midtwentieth century, but a major increase after. The Sahel and the Sahara regions are considered in the projection of IPCC (Christensen et al., 2007) as the most vulnerable to the temperature increase $\left(3.5-4{ }^{\circ} \mathrm{C}\right.$ at the end of the century), and the rapid change in the mid-twentieth century inferred from boreholes suggests that this scenario could be underestimated anyway.

\subsection{Heat-flow and thermal regime of the WAC}

The heat-flow at Saraya is low $\left(31 \pm 2 \mathrm{~mW} \mathrm{~m}^{-2}\right)$, confirming the previous measurements $\left(33 \pm 8 \mathrm{~mW} \mathrm{~m}^{-2}\right)$ in the southern 
domain of the West African Craton (Leo Rise) and extending the areal distribution of these low values. Such low values are only observed in Archean cratons and associated with low radiogenic heat-production in the crust: for instance, the heat-flow at Voisey bay in Canada (Mareschal et al., 2000 ) is $22 \mathrm{~mW} \mathrm{~m}^{-2}$, but the heat-production is only $0.4-$ $0.7 \mu \mathrm{W} \mathrm{m}^{-3}$, which is consistent with a mantle heat-flow of $\sim 10-15 \mathrm{~mW} \mathrm{~m}^{-2}$.

The heat production of the Saraya granite and of the lower crustal rock below are not, however, well known. There are only few Uranium and Thorium data (Ndiaye, 1994; Ndiaye et al., 1997; Pawlig et al., 2006) that lead to a high estimate of the heat-production $\left(1.85 \pm 0.78 \mu \mathrm{W} \mathrm{m}{ }^{-3}\right)$. Other Birrimian granites in West Africa have also rather high value: in Guinea and Sierra Leone (Thiéblemont, 2008 personnal communication) the average heat production is $1.5 \mu \mathrm{W} \mathrm{m} \mathrm{m}^{-3}$. In Ghana (Harcouët et al., 2007), the average heat production of monzogranites is $1.04 \pm 0.44 \mu \mathrm{W} \mathrm{m}^{-3}$. In Burkina Faso, the Tenkodogo-Yamba granitoids have an average heat production of $1.35 \pm 0.49 \mu \mathrm{W} \mathrm{m}^{-3}$ (Naba et al., 2004). Such values do not support the existence of a thick granitic layer, as the lithosphere cannot exceed 200-250 km in West Africa according to the tomographic studies (Ritsema and van Heijst, 2000; Sebai et al., 2006; Pasyanos and Nyblade, 2007; Priestley et al., 2008). The thermal lithosphere defined as the intercept of the continental geotherm and the mantle solidus can be also estimated. The continental geotherm can be calculated with some assumption on the thermal conductivity, providing that the surface heat-flow and distribution of heat source are known. But we can also search for the thickness of the enriched granitic layer that can fit the lithospheric thickness. For a lithosphere thickness of $250 \mathrm{~km}$, there is no solution if the heat-production in the lower crust is equal to $0.4 \mu \mathrm{W} \mathrm{m}{ }^{-3}$ as assumed by Lesquer and Vasseur (1992). If it is only $0.3 \mu \mathrm{W} \mathrm{m}{ }^{-3}$, then the thickness of granite can be estimated to $3-4 \mathrm{~km}$ maximum. The mantle heat-flow in that case is $13-14.5 \mathrm{~mW} \mathrm{~m}^{-2}$, which is comparable to similar estimates in Canada (Mareschal et al., 2000). The site of Saraya is also located in a diamondiferous province (Fig. 1), which requires for the genesis and the preservation of diamonds a heat-flow lower than $40 \mathrm{~mW} \mathrm{~m}^{-2}$ and a lithosphere thicker than $150 \mathrm{~km}$ (Morgan, 1995).

\section{Conclusions}

The measurement at the site of Saraya, in the Precambrian window of the Kédougou-Kéniéba-Inlier, confirms the existence of a very low heat-flow in the southern part of the West African Craton, consistent with the thick lithosphere revealed by several tomographic studies and the occurrence of diamond bearing kimberlites. These measurements also reveal a recent surface temperature increase of $1.5^{\circ} \mathrm{C}$ since the midtwentieth century, consistent with the surface air temperature increase observed at nearby meteorological stations, and ex- tend the surface temperature history in the past before the instrumental record. The temperature increase from 1700 to 1940 was, however, much less important $\left(0.4^{\circ} \mathrm{C}\right)$, which suggests that the dramatic change in the mid-twentieth century is likely related to the global warming that appears stronger in this part of Africa.

Acknowledgements. The heat-flow measurements have been obtained with the cooperation of AREVA Senegal. We especially thank Antonio Benedicto-Esteban, Nicolas Achin, Eric Jaques and Abibou Coly for their help with the different stages of the survey. We also remember Sirimane and Karamba for their help on the field. Jean Claude Mareschal kindly provided his code for the inversion of ground temperature history. We thank Vladimir Cermak and Volker Rath for their constructive reviews. This is IPGP contribution number 3294.

Edited by: J. C. Afonso

\section{References}

Beck, A. E. and Mustonen, E.: Preliminary Heat Flow data from Ghana, Nature Physical Science, 235, 172-174, doi:10.1038/physci235172a0, 1972.

Birch, A. F.: The effects of Pleistocene climatic variations upon geothermal gradients, American Journal of Science, 246, 729760, 1948.

Brigaud, F., Lucazeau, F., Ly, S., and Sauvage, J. F.: Heat flow from the West African Shield, Geophys. Res. Lett., 12, 549-552, doi:10.1029/GL012i009p00549, 1985.

Chapman, D. S. and Pollack, H. N.: Cold spot in West Africa - anchoring the African plate, Nature, 250, 477-478, doi:10.1038/250477a0, 1974.

Christensen, J., Hewitson, B., Busuioc, A., Chen, A., Gao, X., Held, I., Jones, R., Kolli, R., Kwon, W.-T., Laprise, R., Rueda, V. M., Mearns, L., Menéndez, C., Räisänen, J., Rinke, A., Sarr, A., and Whetton, P.: Regional Climate Projections, in: Climate Change 2007: The Physical Science Basis. Contribution of Working Group I to the Fourth Assessment Report of the Intergovernmental Panel on Climate Change, chap. 11, pp. 847-940, Cambridge University Press, Cambridge, United Kingdom and New York, NY, USA, 2007.

deMenocal, P., Ortiz, J., Guilderson, T., Adkins, J., Sarnthein, M., Baker, L., and Yarusinsky, M.: Abrupt onset and termination of the African Humid Period:: rapid climate responses to gradual insolation forcing, Quat. Sci. Rev., 19, 347-361, doi:10.1016/S0277-3791(99)00081-5, 2000.

Diouf, S.: Hydrogéologie en zône cristalline et cristallophyllienne du Sénégal Oriental. Application de la méthode électrique 1D et $2 \mathrm{D}$ à la localisation et à la caractérisation des aquifères du batholithe de Saraya et ses environs, Ph.D. thesis, Cheikh Anta Diop, Dakar, 1999.

Fall, S., Niyogi, D., and Semazzi, F. H. M.: Analysis of Mean Climate Conditions in Senegal (1971-98), Earth Interactions, 10, 1-40, 2006.

Gasse, F.: Hydrological changes in the African tropics since the Last Glacial Maximum, Quat. Sci. Rev., 19, 189-211, doi:10.1016/S0277-3791(99)00061-X, 2000. 
Gasse, F., Chalié, F., Vincens, A., Williams, M. A., and Williamson, D.: Climatic patterns in equatorial and southern Africa from 30,000 to 10,000 years ago reconstructed from terrestrial and near-shore proxy data, Quat. Sci. Rev., 27, 2316-2340, doi:10.1016/j.quascirev.2008.08.027, 2008.

Giannini, A., Saravanan, R., and Chang, P.: Oceanic Forcing of Sahel Rainfall on Interannual to Interdecadal Time Scales, Science, 302, 1027-1030, doi:10.1126/science.1089357, 2003.

Goutorbe, B., Poort, J., Lucazeau, F., and Raillard, S.: Global heat flow trends resolved from multiple geological and geophysical proxies, Geophys. J. Int., 187, 1405-1419, doi:10.1111/j.1365246X.2011.05228.x, 2011.

Gueye, M., Siegesmund, S., Wemmer, K., Pawlig, S., Drobe, M., Nolte, N., and Layer, P.: New evidences for an early Birimian evolution in the West African Craton: An example from the Kedougou-Kenieba inlier, southeast Senegal, South African J. Geology, 110, 511-534, doi:10.2113/gssajg.110.4.511, 2007.

Harcouët, V., Guillou-Frottier, L., Bonneville, A., Bouchot, V., and Milesi, J.-P.: Geological and thermal conditions before the major Palaeoproterozoic gold-mineralization event at Ashanti, Ghana, as inferred from improved thermal modelling, Precambrian Res., 154, 71-87, doi:10.1016/j.precamres.2006.11.014, 2007.

Hartmann, A. and Rath, V.: Uncertainties and shortcomings of ground surface temperature histories derived from inversion of temperature logs, J. Geophys. Eng., 2, 299-311, doi:10.1088/1742-2132/2/4/S02, 2005.

Huang, S. P., Pollack, H. N., and Shen, P. Y.: Temperature trends over the past five centuries reconstructed from borehole temperatures, Nature, 403, 756-758, 2000.

Hulme, M., Doherty, R. M., Doherty, T., New, M. G., and Lister, D.: African climate change: 1900-2100, Climate Research, 17, 145-168, 2001.

Jaupart, C. and Mareschal, J. C.: Heat flow and thermal structure of the lithosphere, in: Treatise on Geophysics, vol. 6, pp. 217-251, G. Schubert, Oxford, 2007.

Kandji, S. T., Verchot, L., and Mackensen, J.: Climate Change and Variability in the Sahel Region: Impacts and Adaptation Strategies in the Agricultural Sector, Tech. rep., United Nations Environment Programme and World Agroforestry Centre, http://www.unep.org/Themes/Freshwater/Documents/ pdf/ClimateChangeSahelCombine.pdf, 2006.

Kooi, H.: Spatial variability in subsurface warming over the last three decades; insight from repeated borehole temperature measurements in The Netherlands, Earth Planet. Sci. Lett., 270, 8694, doi:10.1016/j.eps1.2008.03.015, 2008.

Latil-Brun, M. V. and Lucazeau, F.: Subsidence, extension and thermal history of the West African margin in Senegal, Earth Planet. Sci. Lett., 90, 204-220, doi:10.1016/0012-821X(88)90101-X, 1988.

Lebel, T. and Ali, A.: Recent trends in the Central and Western Sahel rainfall regime (1990-2007), J. Hydrol., 375, 52-64, doi:10.1016/j.jhydrol.2008.11.030, 2009.

Lesquer, A. and Vasseur, G.: Heat-flow constraints on the West African lithosphere structure, Geophys. Res. Lett., 19, 561-564, doi:10.1029/92GL00263, 1992.

Lesquer, A., Bourmatte, A., Ly, S., and Dautria, J. M.: First heat flow determination from the central Sahara: relationship with the Pan-African belt and Hoggar domal uplift, J. African Earth Sciences, 9, 41-48, doi:10.1016/0899-5362(89)90006-7, 1989.
Lesquer, A., Villeneuve, J., and Bronner, G.: Heat flow data from the western margin of the West African craton (Mauritania), Physics of the Earth and Planetary Interiors, 66, 320-329, doi:10.1016/0031-9201(91)90087-X, 1991.

Lézine, A.-M., Hély, C., Grenier, C., Braconnot, P., and Krinner, G.: Sahara and Sahel vulnerability to climate changes, lessons from Holocene hydrological data, Quat. Sci. Rev., 30, 30013012, doi:10.1016/j.quascirev.2011.07.006, 2011.

Mareschal, J.-C. and Beltrami, H.: Evidence for recent warming from perturbed geothermal gradients: examples from eastern Canada, Clim. Dynam., 6, 135-143, doi:10.1007/BF00193525, 1992.

Mareschal, J. C., Poirer, A., Rolandone, F., Bienfait, G., Gariepy, C., Lapointe, R., and Jaupart, C.: Low mantle heat flow at the edge of the North American continent, Voisey Bay, Labrador, Geophys. Res. Lett., 27, 823-826, 2000.

Mareschal, J. C., Jaupart, C., Rolandone, F., Gariépy, C., Fowler, C. M. R., Bienfait, G., Carbonne, C., and LaPointe, P. R.: Heat flow, thermal regime, and elastic thickness of the lithosphere in the Trans-Hudson Orogen, Canadian J. Earth Sciences, 42, 517532, doi:10.1139/e04-088, 2005.

Meukam, P., Jannot, Y., Noumowe, A., and Kofane, T.: Thermo physical characteristics of economical building materials, Construction and Building Materials, 18, 437-443, doi:10.1016/j.conbuildmat.2004.03.010, 2004.

Michel, J.: La province kimberlitique et diamantifère de Kéniéba, Mali, Africa Geoscience Review, 3, 231-246, 1996.

Misener, A. and Beck, A. E.: The measurement of heat flow over land, in: Methods and Techniques in Geophysics, pp. 10-61, S.K. Runcorn, New York, 1960.

Moberg, A., Sonechkin, D. M., Holmgren, K., Datsenko, N. M., and Karlèn, W.: Highly variable Northern Hemisphere temperatures reconstructed from low- and high-resolution proxy data, Nature, 433, 613-617, doi:10.1038/nature03298, 2005.

Morgan, P.: Diamond exploration from the bottom up: regional geophysical signatures of lithosphere conditions favorable for diamond exploration, Journal of Geochemical Exploration, 53, 145$165,1995$.

Naba, S., Lompo, M., Debat, P., Bouchez, J. L., and Béziat, D.: Structure and emplacement model for late-orogenic Paleoproterozoic granitoids: the Tenkodogo - Yamba elongate pluton (Eastern Burkina Faso), Journal of African Earth Sciences, 38, 41-57, doi:10.1016/j.jafrearsci.2003.09.004, 2004.

Ndiaye, P. M.: Evolution au Proterozoique Inférieur de la Région Est - Saraya (craton de L'Afrique de L'Ouest, Sénégal-Mali). Tourmalinisations, Altérations Hydrothermales et Minéralisations Associées, Ph.D. thesis, Université C.A.Diop, Dakar, 1994.

Ndiaye, P., Dia, A., Vialette, Y., Diallo, D., Ngom, P., Sylla, M., Wade, S., and Dioh, E.: Données pétrographiques, geochimiques et géochronologiques nouvelles sur les granitodes du Paléoprotérozoïque du Supergroupe de Dialé-Daléma (Senégal Oriental): Implications pétrogénétiques et géodynamiques, J. African Earth Sciences, 25, 193-208, doi:10.1016/S08995362(97)00098-5, 1997.

Pasyanos, M. E. and Nyblade, A. A.: A top to bottom lithospheric study of Africa and Arabia, Tectonophysics, 444, 27-44, doi:10.1016/j.tecto.2007.07.008, 2007. 
Patricola, C. and Cook, K.: Dynamics of the West African monsoon under mid-Holocene precessional forcing: Regional climate model simulations, J. Climate, 20, 694-716, doi:10.1175/JCLI4013.1, 2007.

Pawlig, S., Gueye, M., Klischies, R., Schwarz, S., Wemmer, K., and Siegesmund, S.: Geochemical and $\mathrm{Sr}-\mathrm{Nd}$ isotopic data on the Birimian of the Kedougou-Kenieba Inlier (Eastern Senegal): Implications on the Palaeoproterozoic evolution of the West African Craton, South African Journal of Geology, 109, 411427, doi:10.2113/gssajg.109.3.411, 2006.

Priestley, K., McKenzie, D., Debayle, E., and Pilidou, S.: The African upper mantle and its relationship to tectonics and surface geology, Geophys. J. Int., 175, 1108-1126, doi:10.1111/j.1365246X.2008.03951.x, 2008.

Rath, V., González Rouco, J. F., and Goosse, H.: Impact of postglacial warming on borehole reconstructions of last millennium temperatures, Clim. Past, 8, 1059-1066, doi:10.5194/cp-8-10592012, 2012.

Rimi, A. and Lucazeau, F.: Heat flow density measurements in northern Morocco, J. African Earth Sciences, 6, 835-843, 1987.
Ritsema, J. and van Heijst, H.: New seismic model of the upper mantle beneath Africa, Geology, 28, 63-68, 2000.

Sass, J. H. and Behrendt, J. C.: Heat Flow from the Liberian Precambrian Shield, J. Geophys. Res., 85, 3159-3162, 1980.

Sebagenzi, M. N., Vasseur, G., and Louis, P.: Recent warming in southeastern Zaire (Central Africa) inferred from disturbed geothermal gradients, Palaeogeography, Palaeoclimatology, Palaeoecology, 98, 209-217, doi:10.1016/00310182(92)90199-F, 1992.

Sebai, A., Stutzmann, E., Montagner, J.-P., Sicilia, D., and Beucler, E.: Anisotropic structure of the African upper mantle from Rayleigh and Love wave tomography, Physics of the Earth and Planetary Interiors, 155, 48-62, doi:10.1016/j.pepi.2005.09.009, 2006.

Takherist, D. and Lesquer, A.: Detection of Significant Regional Variations in Heat-Flow in Algeria, Canadian J. Earth Sciences, 26, 615-626, doi:10.1139/e89-053, 1989.

Vasseur, G. and Lucazeau, F.: Bounds on paleotemperatures and paleoclimatic corrections, Zbl. Geol. Paleontol., 1, 17-24, 1983.

Zeng, N.: Drought in the Sahel, Science, 302, 999-1000, doi:10.1126/science.1090849, 2003. 